\title{
JAKUS János \\ A magyar rádió- és rádióelektronikai felderítés szervezeti változásai 1990-ig
}

Az egyes történelmi korok technikai fejlettségi színvonala meghatározó módon hatott a hírszerzés hatékonyságára, különösen a XIX-XX. században, amikor egyre-másra következtek be a tudományos és technikai felfedezések egyebek mellett a fizika a kémia és a matematika területein.

Szakmai körökben közismert, hogy a rádiófelderítés ${ }^{1}$ első, hadászati döntéseket befolyásoló eredménye 1914 őszén Kelet-Poroszországban következett be, amikor is a német hírszerzés lehallgatta az oroszok kódolatlan rádió üzeneteit, amelynek eredményeként a tennenbergi csatában szétverték a támadó 1. és 2. orosz hadsereget. Az orosz vezérkar rejtjelző irodájának fönöke ANDREJEV őrnagy, aki árulástól tartott, késve rendelte el a kódkönyvek kiosztását a hadseregek számára, így a hadmüveleti területen kialakult válságos helyzetben a vezetési szintek közötti hírváltás, adott esetben parancsok kiadása, nyílt szövegben történt. HINDENBURG tábornagy visszaemlékezésében nem tett említést arról, hogy az általa vezetett 8 . német hadsereg tennenbergi győzelmében milyen szerepet játszott a német rádiófelderítés. Ezzel szemben POKORNY, visszaemlékezésében arról számolt be, hogy HINDENDURG tábornagynak a tennenbergi győzelmet követő kelet-poroszországi sikereihez jelentős részben hozzájárultak az általa megfejtett és a németeknek átadott orosz rejtjel kulcsok. Vagyis az Osztrák-Magyar Monarchiában, minden ellenkező véleménnyel szemben, a rádió híradásnak a polgári és katonai kommunikációban történő megjelenésétől kezdődően, megfelelő jelentőséget tulajdonítottak és úgy a hadseregben, mint a rendvédelmi testületeknél e szervezeti egységeket alkalmazták a nyílt és a rejtett hírváltások megfigyelésére és megfejtésére. ${ }^{2}$

\section{A rádiófelderítés kezdete az Osztrák-Magyar Monarchiában}

Az Osztrák-Magyar Monarchia hadseregében, mint Európa fejlettebb országaiban általában — követve a németeknek a hadszervezés és vezetés területén, illetve a hadeljárások gyakorlatában bevezetett újdonságait - már a háború előtt megjelentek a híradástechnika új vívmányai: a morzetávíró, majd a távbeszélő és a rádió adó-vevő. E vezetéstechnikai berendezések és módszerek a katonai vezetés/irányítás szervezeti elemeinek operativitását jelentősen támogatták, mivel alkalmazásukkal lehetővé vált a parancsok/intézkedések gyorsan és titkosan történő továbbítása. A híradástechnika újdonságai magukkal hozták a továbbításra kerülő híranyagok kódolásának-, és dekódolásának fejlődését, illetve az e célt szolgáló berendezések korszerüsítését, vagy újabbak kialakítását. ${ }^{3}$

Az Osztrák-Magyar Monarchia véderejében 1896-tól vezényeltek hallgatókat a Tullnban müködő távírász iskolába, ahol a vegyes nemzetiségü legénységből német, magyar és szláv nyelvü távírászokat, illetve a rendszeresítésre került más hírközlő eszközök kezelöszemélyzetét képezték ki. Az iskola növendékei elsajátították a rejtjelzés alapvető fortélyait, vagyis a kódkönyvek kezelését, a rejtjelzéssel/rejtjelfejtéssel kapcsolatos alapismereteket, illetve az ahhoz konstruált technikai berendezések használatát. ${ }^{4}$

1914. VII. 31-én, Osztrák-Magyar Monarchia véderejének mozgósítását követően, a hírszerzési feladatokat végző Nyilvántartó Irodával (Evidenzbüro) való szoros együttmüködés követelményét szem előtt tartva, létrehozták a Hadsereg-főparancsnokság Hírszerző Osztályát, amelynek feladata a tábori hírszerzés megszervezése és fenntartása volt. Az osztály eredetileg, annak főnökéből a közös külügyminisztérium képviselőjéből, a tolmács-, az információkezelési-, az orosz-, és a balkáni hírszerző csoportból állt, amelyet később az olasz-, a román-, a személyi-, az útlevél-, az utazási-, a propaganda csoporttal, illetve a rádiólehallgató és rejtjelfejtő szolgálattal egészítettek ki. A részlegekben és a szakági szolgálatokban több magyar nemzetiségü, vagy magyarországi illetőségű személy is szolgált. A Hírszerző Osztály első parancsnoka Oskar HRANILOVIC-CVETASSIN ezredes volt, akit beosztásában, 1917-ben Maximilian RONGE ezredes követett. (RONGE századosként 1907-től teljesített szolgálatot a Nyilvántartó Irodában, és 1908-ban ő vette át Alfred REDL örnagytól a hírszerző csoport vezetését. Osztrák-Magyar Monarchia haderejében 18-féle hírszerző szolgálati ág müködött, többek között a távbeszélö-, és rádió lehallgató szolgálatok. A másfél tucatnyi szolgálatot olyan precizitással és hatékonysággal müködtették, hogy a szervezési alapelveket a háború befejezését követően, az utódállamok hírszerző szolgálatainak kialakításakor is alapul lehetett venni. ${ }^{5}$

A Hírszerző Osztály a Hadsereg-föparancsnoksággal együtt 1914. augusztus 17-től Premyslbe, majd Neu-Sandecbe, míg november 13-tól Teschenbe, és végül 1917-től Badenbe települt. A Hírszerző Osztály legismertebb rádiófelderítő és rejtjelfejtő szakembere POKORNY Hermann százados volt (I.sz.melléklet), aki 18, — más helyen hivatkozva 19 - orosz rejtjelkulcsot fejtett meg, amelyeknek 
az ismeretében az hadvezetés megfelelő ellenintézkedéseket tudott foganatosítani az orosz csapatok támadásának elhárítására. ${ }^{6}$

A sikeres rádiófelderítés és rejtjelfejtés sorából három olyan példát érdemes megemlíteni, amely jól példázza a POKORNY által vezetett csoport munkájának jelentőségét. Az első, amikor a rejtjelfejtő csoport 1914. decemberében 240 távirat-csomagot dolgozott föl, amelyekből kiderült az orosz fél támadó szándéka, illetve annak helye és időpontja. Az orosz támadást sikerült megállítani és a 9. német, valamint a Osztrák-Magyar Monarchia 1. hadserege visszaszorította az orosz csapatokat kiindulási állásaikba. A másik esetben, 1915. márciusában, 205 ellenséges távirat-csomag megfejtésével elösegítették a német és az osztrák-magyar csapatok Gorlicénél elért hadműveleti sikereit. A harmadik esetben pedig 53 távirat megfejtésével jelentős mértékben járultak hozzá Brest-Litovszk város 1915. VIII. 25-én történt elfoglalásához. MACKENSEN tábornok a 11. német hadsereg parancsnoka elöterjesztésében a következők szerint nyilatkozott POKORNY munkájáról: "POKORNY őrnagy megfejtései BresztLitovszk várakozáson felüli gyors elfoglalását eredményezték."”

POKORNY és csoportja 1914. IX. 6. és 1916. III. 1. között 10 000-12 000, lehallgatott rejtjelzett táviratot fejtett meg. Franz Conrad von HÖTZENDORF tábornagy, az Osztrák-Magyar Monarchia haderejének vezérkari főnöke, a háború után megjelent visszaemlékezésében név szerint is megemlékezett POKORNY rádiófelderítő, és rejtjelfejtő sikereiről. ${ }^{8}$

Az Osztrák-Magyar Monarchia mind a hat hadsereg-parancsnokságán, és azok alárendeltségeiben a hadtest-parancsnokságokon is müködtettek hírszerző csoportok ${ }^{9}$, közöttük rádiólehallgató örsök, amelyek közvetlenül az illetékes hadtest vezérkari főnökének irányítása alatt álltak. ${ }^{10}$ A rádiófelderítésből származó adatokat a hadsereg-parancsnokságoknál létrehozott rejtjelmegfejtő csoportokhoz, majd az eredményeket a hadsereg-parancsnokságokhoz, illetve a Fővezérséghez továbbították. A „Nagy Háború” alatt az Osztrák-Magyar Monarchia csapatainak frontvonalain összefüggő rádiólehallgató állomások müködtek, amelyek rendszerbe szervezve gyüjtötték, dekódolták és értékelték az ellenségről szerzett információkat. Ezt a rendszert POKORNY Hermann szervezte meg és 1917-től, kisebb-nagyobb megszakításokkal irányította is. Az 1916. évi román támadás visszaverésében jelentős szerepet vállaltak a Magyar Királyi Honvédség, illetve a magyarországi sorozású közös alakulatok. ${ }^{11}$ Ilyenek voltak: többek között a TANÁRKY Béla tábornok által vezetett 51. honvéd gyaloghadosztály, vagy a közös, de székelyföldi sorozású 82. gyalogezred, amely egyben az uralkodó háziezrede is volt. $^{12}$

A hadmüveletekben résztvevő és az arcvonal mögött harcfelderítési feladatokat végrehajtó MADERSPACH Viktor százados, visszaemlékezésében beszámol arról, hogy felderítő csoportja hogyan valósította meg a román telefonvonalak lehallgatását Havasalföldön, és az így szerzett információkat milyen hatékonysággal használta föl a német és az osztrák-magyar hadvezetés a nagyszebeni csatában. $^{13}$

A békében, de a háború alatt is, a az Osztrák-Magyar Monarchia egyes diplomáciai képviseletein a katonai attasé szolgálatok — az Evidenzbüroval együttmüködve — rezidentúrákat müködtettek, amelyek tevékenységének alapját mindenek előtt a széleskörű ügynöki hálózat képezte, ${ }^{14}$ de az információszerzés fontos eleme volt a telefonlehallgatás és a rádiófelderítés is. ${ }^{15}$

A hírszerzés területén dolgozó kitünően felkészült szakemberek, az Osztrák-Magyar Monarchia széthullása után szerepet vállaltak az utódállamokban, köztük Magyarországon is. Körükből számosan visszatértek hazájukba, a Magyar Királyságba, illetve új otthonra találtak Magyarországon. Többek között: POKORNY Hermann és SZTOJAKOVICS Demeter vált igazán ismertté nálunk a régi gárdából. SzTOJAKOVICs Demeter volt az, aki megszervezte a magyar hírszerzés/elhárítás önálló intézményeit, és ö volt az is, aki SZTÓJAY Döme néven, mint vezérezredes berlini meghatalmazott követ, majd a német megszállást követően, az ország miniszterelnöke vált ismertté. POKORNY szintén részese volt a magyar hírszerzés/elhárítás megszervezésének, de ő csapatszolgálatait követően - miskolci vegyesdandár parancsnok, altábornagyi rendfokozatban, amely abban a korban egyáltalán nem volt jelentéktelen beosztás, mint azt PUSZTASZERI László állítja ${ }^{\mathbf{1 6}}$ - megmaradt a rejtjelfejtés területén. A II. világháború utáni időkben, mint nyugállományba helyezett vezérezredes vállalt állami feladatokat: ö lett a jóvátételi kormánybiztos. POKORNY unokaöccse (Franciszek POKORNY), aki szintén képzett rádiófelderítő és rejtjelfejtő volt, Lengyelországban telepedett le. A legújabb kutatások szerint nagyrészt neki köszönhetik a lengyelek, hogy Varsó alatt szétverték a TUHACSEVSZKIJ tábornok által vezetett túlerővel támadó szovjet hadsereg egységeit és kiűzték azokat Lengyelország területéről. Ugyancsak ö volt az, aki a poznani egyetemen kriptográfiai kurzust szervezett és vezetett. A keze alatt felnőtt növendékek egy része a háború alatt Londonban közremüködött a német ENIGMA rejtjelkulcsának feltörésében. ${ }^{18}$ 


\section{A magyar katonai rádiófelderítés újjászervezése}

A két világháború között, illetve a második világháború során a rádiófelderítés világszerte nagykorúvá vált, és a szemben álló felek által müködtetett szolgálati ágak jelentős mértékben járultak hozzá a diplomáciai csatározások eredményeihez, majd pedig az újabb világháborúban, a hadászati és hadmúveleti sikerekhez. A rádiófelderítés második világháborús eredményeiről számos esetet említ a szakirodalom. Ilyen például a német ENIGMA rejtjező berendezés kulcsának az angolok által történt feltörése, vagy az ún. Vörös Zenekar néven ismertté vált, Európát behálózó szovjet kémszervezett németek által történt felszámolása. Ennek a szervezetnek a tagja volt többek között RADÓ Sándor, aki a háború után Magyarországon, mint kartográfus és földrajz tudós, illetve a Dóra jelenti, címü kötet szerzője vált ismertté.

A Magyar Királyság önálló hírszerző szervezete 1918-ban SzTOJAKOVICS Demeter vezetésével a Hadügyminisztérium I. osztályaként kezdte meg müködését. A minisztérium VIII. osztálya a Katonapolitikai osztály volt, amely TÁNCZOS Gábor vezérőrnagy irányításával a tárca külkapcsolatainak szervezésével foglalkozott, és szorosan együttmüködött a hírszerző osztállyal. A 1919-ben a diktatúra idején, a Hadügyminisztérium, illetve a Hadügyi Népbiztosság V. osztály foglalkozott a hírszerzés megszervezésével, amely később a Vörös Hadsereg Főparancsnokság II. csoportjaként végezte ezt a feladatot. A magyarországi politikai helyzet tisztázódását követően 1919. november 17-től a Fővezérség II. csoportja, élén SZTOJAKOVICS Demeterrel, vette át a hírszerzés irányítását. ${ }^{19}$

A rejtés időszakában (1920-1927) a Honvédelmi Minisztérium VI. Csoportfőnöksége tervezte, szervezte és végezte a hírszerzéssel kapcsolatos feladatokat. Itt kapott beosztást POKORNY Hermann, aki rövid idő alatt megszervezte, és első alkalommal 1925-ig vezette a rádiófelderítő és rejtjelfejtö szolgálatot. ${ }^{20}$ A rejtési időszakot követően GöMBÖs Gyula miniszterelnöksége idején, 1932-től a HM VI. Csoportfőnökségéből megalakításra került a Honvéd Vezérkar. A VI/2 osztályból pedig létrehozták a VKF-2 osztályt, amely a magyar hírszerzés/felderítés és elhárítás egyik legfontosabb szervezete lett 1945-ig. (A VKF-2 az önállóságát az Állambiztonsági Központ létrehozását követően is megörizte annak ellenére, hogy annak támogatására kötelezve volt.) ${ }^{\mathbf{2 1}}$

\section{A VKF-2 szervezetében meghatározó jelentőséggel bírtak a rádiófelderítés és a rejtjelfejtés szer- vezeti egységei}

A rádiófelderítés és a rejtjelfejtés szervezetei külön váltan müködtek ebben az időben. A szakterülettel foglalkozó egyes civil kutatók tévesen értelmezik a VKF-2 korabeli szervezeti rendjét, szerintük a két szakterület azonos szervezeti egységben tevékenykedett. A rádiófelderítést huzamosabb időn keresztül, a kezdetben három lehallgató állomást müködtető, MELCZER Dezső alezredes által vezetett csoport végezte. Az állomások munkahelyeinek száma a felderített adóállomások száma szerint bővülhetett. Így létezett angol, francia, olasz, török, spanyol stb. munkahely, amelyek a lehallgató állomások között került leosztásra. Minden felderített rádióállomást, 2-3 rádióvevőt alkalmazó lehallgató őrs megszakítás nélkül megfigyelés alatt tartott. A lehallgató állomások a testőrlaktanyában, a Verbőczy utcában, és a Vakok Országos Intézetében települtek, ez utóbbi helyen 40 fö látássérült embert foglalkoztattak. Az állomásokon mindösszesen 100-120 ember dolgozott folyamatosan fárasztó munkatempóban, amit a megfelelő munkaszervezéssel és meglehetősen jó anyagi dotációval kompenzáltak. ${ }^{22}$

Némely kutató azt állítja, hogy e munkaterületeken föleg híradó szakterületen szolgált katonaviselt személyzetet alkalmaztak. Nem volt ilyen megkötés és szempont a rádiólehallgató személyzet kiválogatásánál érvényben. Ellenben különös gondot fordítottak az alkalmazottak rátermettsége-, elkötelezettsége-, és mindenek előtt a megbízhatóságuk vizsgálatára. A rádiólehallgatások kitűnő eredményességgel folytak. Az egykori levéltári adatok és újabb keletü kutatási eredmények nem számolnak be arról, hogy ezen a területen dekonspiráció, vagy árulás történt volna.

A szakterület egyes kutatói azonban ráirányítják az érdeklődők figyelmét arra, hogy az „X” alcsoport vezető munkatársai a háború alatt közvetlenül is kapcsolatban álltak szövetséges, jelesül német kollégáikkal, illetve a német hírszerzés és elhárítás szervezeteivel. Ezzel nem lehet semmi probléma, de az nem történhetett meg, hogy beosztott munkatárs tartott fenn ilyen jellegü kapcsolatokat. A magam részéről ezt az állítást, mint a tárgyban folytatott kutatás hozzáadott értékét, tényként nem tudom elfogadni, mivel a szakterület belső rendje beosztotti szinten a személyhez köthető kapcsolattartást és adatszolgáltatást nem türte/türi el. Ugyanis az ilyen jellegü kapcsolatok léte esetében fenn áll az árulás veszélye és azt egyetlen titkosszolgálat sem tolerálja. Intézményesített kapcsolattartás viszont, kölcsönös információcsere tekintetében természetesen egy bizonyos vezetési szintig és tartalmi határig létezett, mint ahogyan ez ma is fennáll a szövetséges hírszerzö közösségen belül. ${ }^{23}$ 
A MELCZER csoport a KOFFA alárendeltségében végezte feladatait, míg az „X” alosztály, vagyis rejtjelfejtés önálló szervezeti egységként a VKF-2 osztályvezetőjének alárendelve, szigorú rezsim szabályok betartásával tevékenykedett a reaktivált POKORNY Hermann altábornagy vezetése alatt, aki 1935-1938 között állt az alosztály élén. POKORNYT, SOLYMOSSY alezredes és KUDRICZY István vk. őrnagy nyomására HENNYEY Gusztáv a VKF-2 osztályvezetője, elmozdította az állásából. POKORNYt PETRIKOVITS Viktor ezredes váltotta az alosztályvezetői székben.

Az alosztály a budai várban, a Színház utca 7. szám alatt állomásozott. ${ }^{24}$ A szervezet múködéséröl SZENTPÉTERY György vk. ezredes, a VKF-2 egykori vezető beosztású tagja - a KOFFA egykori vezetője -, 1950-ben történt letartóztatását követően adott tájékoztatást az Államvédelmi Hatóság embereinek. SZENTPÉTERYtől az Államvédelmi Hatóság a rádiólehallgató szolgálat müködési rendjéről és az egykori személyzet felől érdeklődött, feltehetően azért, mert ebben az időben történtek erőfeszítések az Államvédelmi Hatóság részéről a diplomáciai hírcsatornák lehallgatásának megszervezésére, illetve megerösítésére, amelyhez felkészült szakemberekkel az időtájban nem rendelkeztek. Annak ellenére sem, hogy a KATPOL-tól átirányították az ott alkalmazott egykori szakembereket, akiknek a zömét különféle ürügyekkel börtönbe zárták. A büntetésük ideje alatt e szakembereket a rádifelderítés és rejtjelfejtés területein az Államvédelmi Hatóság visszafoglalkoztatta, az ilyen presszió más katonai szakterületen dolgozó elismert szakemberekkel is gyakorta előfordult. A „,szigorú felügyelet” igazán lehetővé tette a biztonságos tevékenységet. Egyébként ez történt SZENTPÉTERY György ezredessel is, aki a II. világháborút követően a KATPOL munkatársa lett.

A MELCZER csoport a lehallgatott anyagokat állomásonként összerendezve a KOFFA-hoz, illetve az „X” alosztályhoz továbbította, ahol megtörténtek a táviratok megfejtése, amelyeket a osztályvezetőnek adtak át. Így lehetőség nyílt arra, hogy a lehallgatott táviratokat számszakilag és megfejtettség szerint is össze lehetett hasonlítani. Ennek azért volt jelentősége, mert az „X” alosztály ösztönözve volt a minél eredményesebb munkára, mivel nem fektethette el az oda beérkező anyagokat. Másrészről pedig kontrollálni lehetett a MELCZER csoport lehallgatott táviratainak pontosságát. A szakág munkájának a szervezettsége, vezetettsége és eredményei jelentős mértékben elősegítették, hogy a VKF-2 folyamatosan ellátta értékelt híranyaggal a legfelsőbb állami és katonai vezetést úgy béke, mint háborús körülmények között. Az „X” alosztály nem adott ki sajáthatáskörben értékelt adatokat, a felhasználók tájékoztatását a NYIL alosztály végezte. A rejtjelfejtés szigorúan elzárt térben folyt, ahová az osztály vezetője sem léphetett be. Az ott folyó munkáról az alosztály vezetöje referált az osztályvezető felé. SZENTPÉTERY szerint a 1930-as évek közepétől az "X" alosztály teljesítménye közép-európai viszonylatban kimagaslóan az első helyen állt, ugyanakkor tényként állapította meg, hogy német és az olasz partnereket biztosan felülmúlta. ${ }^{25}$

A veszélyeztetettség időszakában, illetve háborús viszonyok közepette a seregtest parancsnokságokat rádiófelderítésből származó adatokkal kezdetben a 101. híradó ezred bázisán létrehozott 101/II. rádiófelderítő-zászlóalj látta el, amelyet szakmai szempontból a VKF-2 irányított. A harcászati, hadmüveleti szintủ rádiófelderítés kezdete a 1930-as évek közepére tehető. A csapatszintű rádiófelderítés már a kezdetek-kezdetén is sikerrel oldotta meg feladatait, amennyiben sikerült a kis-antant államok csapatmozgásait, gyakorlatait, illetve a csapategységeit nyomon követni és beazonosítani. Az alegységek első gyakorlatainak egyikét SZENTPÉTERY György vk. százados, a KOFFA vezetője irányította és azonnal nagy feltünést keltett azzal, hogy sikerült a cseh hadsereg Brünn környéki manővereit felderíteni és az abban szereplő egységeket, illetve azok feladatait megállapítani. A rádiófelderítés által szolgáltatott adatokat az attaséi szolgálaton keresztül a VKF-2 vezetője visszaellenőriztette. A kapott eredmények láttán, amelyek visszaigazolták a korábbi jelentések tartalmának hitelességét döntés született a csapatszintü rádiófelderítés erőinek növelésére. ${ }^{26}$

A háború menetében a 101. és a 102. önálló rádiófelderítő-zászlóaljak (RÁF) végezték ezt a feladatot. A rádiófelderítő-zászlóaljak alegységei a hadsereg frontvonalai mögött települve, nagy pontossággal mérték be az ellenséges adóállomások helyét, és állapították meg azok hovatartozását, valamint szerepüket az ellenség vezetési rendszerében.

A 101. önálló RÂF zászlóalj eredetileg a 101/II. híradó zászlóalj volt. ${ }^{27}$ Az ezred II. zászlóalja és a 6. lehallgató századának összevonását a HM 42000/eln. 1/a-1942 sz. intézkedésében rendelte el a honvédelmi miniszter, állomáshelyéül pedig Nagyváradot jelölte ki. A zászlóalj 3. lehallgató százada és a kiértékelö részlege Budapesten maradt. A 3. lehallgató századra építve a HM 43000/eln. 1/a-1943. sz. miniszteri intézkedés elrendelte a 102. rádióhírszerző zászlóalj felállitását, amely a VKF-2 közvetlen alárendeltségébe került. Vagyis minősítését tekintve hadászati szinten tevékenykedő rádió felderítő alegységnek minősült, amelynek az állományába szintén beosztottak 30 látássérült embert. Szinte ezzel egy időben a 101. RÁF zászlóaljat állomáshely változtatása nélkül, alárendelték a kolozsvári IX. had- 
testnek. A háború menetében a zászlóalj áttelepülést hajtott végre Csorna körzetébe, majd pedig a Német Birodalom ausztriai területén Purgstall, illetve Schérding területén megadta magát az amerikaiaknak. ${ }^{28}$

$\mathrm{Az}$ „X” alosztály a háború alatt folyamatosan és eredményesen folytatta tevékenységét, míg végül is alsó-bajorországban (állítólag Eggenfelden körzetében) PETRIKOVICS Viktor ezredes vezetésével megadta magát az amerikaiaknak és részükre 90 kódkönyvet adott át. A személyzet nagyobb hányada nem tért vissza Magyarországra. PETRIKOVITSsal együtt még néhány munkatársa döntött úgy, hogy hazatér. Őket a magyar állambiztonsági szervezetek (KATPOL, ÁVO/ÁVH) kezdetben alkalmazták, majd pedig többeket közülük az Államvédelmi Hatóság örizetbe vett, és kényszer alatt felhasználta tudásukat és tapasztalataikat.

A két világháború között Magyarországon a rendvédelmi szervezetek is folytattak rádiófigyelést. Különösen a csendőrség volt aktív ezen a területen, amikor is már a 1920-as évek végén 21 rádiófigyelő állomást helyeztek üzembe, amelyeknek a külföldi nyílt rádióállomások magyar vonatkozású adásainak a figyelemmel kísérése volt a feladata. „A külföldi rádióadások megfigyelését a nyomozóosztály parancsnokság rádió-megfigyelő állomása végezte, melyet 1935-ben már központi rádiófigyelő állomásnak neveztek. Rádiófigyeléssel foglalkoztak még a nyomozó alosztályok, valamint a híradó örsök felállítása után ezen híradó őrsök is. ${ }^{29}$ A Magyar Királyi Csendőrség központi rádió megfigyelő állomása 1935-ben több mint 200 megfigyelést végzett. 1936-ban min egy 160-at, 1942-ben csupán az ungvári híradó őrs 500-at. A Magyar Királyi Csendőrség rádiófigyelői meglepően jól érzékelték a nyugati hatalmak propagandájában bőven fellelhető népámítást és szemforgatást. Találóan jellemzi például DEÁK Kálmán híradó tiszthelyettes a párizsi adásokat a Csendőrségi Lapok 1942. II. 1-jei számában közzétett „Rádió hullámok Magyarország ellen” címü írásában: „Az általános hírszolgálat tartalmát angol módszer szerint állították össze, azaz a valóság öszinte feltárása nem volt szokásuk . . , 30

\section{A magyar rádiófelderítő-szolgálat újjá szervezése és múködése a koalíciós időkben és a hideghá- ború korában.}

Nem kétséges, hogy a magyar rádiófelderítés fejlődését és fejlesztését a hidegháború korában az ország orosz megszállásának ténye, illetve 1955-től a Varsói Szerződés tagsága alapvetően meghatározta. A hazai szakértők véleménye az, hogy ennek a helyzetnek szigorúan szakmai szempontokat figyelembe véve, voltak pozitív oldalai. A katonai konfliktus kirobbanásának veszélyével terhelt szembenállás időszakában mindkét tábor jelentős sikereket ért el a rádiófelderítés területén, az eredményekről a szakirodalom, illetve a szakterület még köztünk élő művelői különböző kiadványban, tudományos konferenciák előadásaiban számos alkalommal beszámoltak.

1945. január közepén az Ideiglenes Nemzeti Kormány Debrecenben felállította a Honvédelmi Minisztériumot. A honvédelmi minisztériumon belül - 1945. III. 3-án - létrehozták a Katonapolitikai Osztályt, ${ }^{31}$ amelynek szervezete a hírszerzést illetően az alábbi osztályokat foglalta magába: Nyilvántartó alosztály (NYIL) benne a rádiócsoporttal, Hírszerző alosztállyal és „X” (rejtjelző, rejtjelfejtö) alosztállyal.

Ez a szerény szervezet, és annak korlátozott képességei, jelentette a háború utáni szervezett magyar rádiófelderítés kezdetét. Az adatforrások között müsorszórók, hírügynökségek, diplomáciai adók,

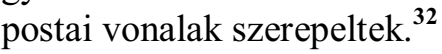

Miután a politikai pártok erőviszonyaiban radikális változások következtek be, annak velejárójaként átalakultak az ország erőszakszervezetei is, amelyek elsősorban a szovjet minta követésében mutatkoztak meg. 1947. II. 14-én a korábbi KATPOL egy részéből megalakították a HM Katonapolitikai Csoportfönökséget RÉVÉSz Géza altábornagy vezetésével. A Magyar Államrendőrség Államvédelmi Osztályából pedig EISENBERGER Benjámin (Péter Gábor) vezetésével a BM Államvédelmi Hatóságot. A Katonapolitikai Csoportfönökség átköltözött a XI. kerületi Bartók Béla út 24-26. sz. alatti laktanyába (korábban Hadik laktanya). A Nyilvántartó Osztályhoz tartozó rádió felderítő erőket ugyanoda helyezték át.

Már az Államrendőrség Államvédelmi Osztály megalakulásakor (1946) is fontos feladatnak tekintették a titkos rádióállomások, illetve adók felderítését. Az Államrendőrség Államvédelmi Osztály IX. alosztályának volt feladata a levél-, távirat- és telefon ellenőrzés, a fényképezés rejtjelzés és helyszínelés, valamint a rádiófelderítés és elhárítás.

A Belügyminisztérium Államvédelmi Hatósága megalakulásával a kezdetektől, azaz 1948-tól a „D” ügyosztálya foglalkozott a rádiófelderítéssel egészen 1949 végéig, amikor is az ÁVH kivált a BM alárendeltségéből, és mint önálló szervezet a Minisztertanács „kontrolja” alá került. Az önállóvá vált 
Államvédelmi Hatóságon belül a III. főosztály foglalkozott a telefon és rádiólehallgatással, illetve a rádiófelderítéssel. A soron következő átalakítás lényege abban foglalható össze, hogy az egyre erősödő és 1950-re teljes önállóságot élvező Államvédelmi Hatóság magához vonta a rádiófelderítés diplomáciai szolgálatokat ellenőrző részét. EISENBERGER Benjámin (PÉTER Gábor) KATPOL-tól, illetve később a katonai hírszerzéstől áthelyeztette, vagy letartóztatásukat követően, kényszeríttette a legképzettebb szakembereket a rádiófelderítéshez köthető szakfeladatok ellátására. ${ }^{33}$

1951-ben a szervezeti fejlesztések következtében a rádió elhárítás megmaradt a IX. osztálynál, ugyanakkor megalakításra került a XV. osztály, ahol a rejtjelfejtéssel foglalkoztak. ${ }^{34} 1955$-töl ez az osztály önálló osztállyá fejlődött. 1956-ot követően az Államvédelmi Hatóságot végleg feloszlatták, de a föosztályait a belügyminisztérium szervezeti egységébe sorolták. A II. csoportfőnökség kapta a hírszerzéssel/elhárítással kapcsolatos feladatokat. A II/12. osztály volt a rejtjelző központ, míg a II/16. osztály a rádiófelderítéssel foglalkozott egészen 1962-ig.

1962-ben kialakították a III. Főcsoportfönökséget, amelynek az V. Operatív Technikai Csoportfönöksége foglalkozott a rádiófelderítés feladataival, pontosabban: a rádiófelderítéssel, a rádiólefigyeléssel, a távol- és közel irányméréssel, a diplomáciai lehallgatással, a rádióadatok nyilvántartásával és a rejtjelfejtéssel.

A soron következő változás a polgári hírszerzés szervezetében 1972-ben történt, amikor is megalakult a BM III. Főcsoportfönökség, amelynek I. (hírszerző) csoportfönökségébe került a rejtjelfejtés, rejtjelzés (III/I-13. osztály), míg a rádiófelderítés és elhárítás feladatait a III/5. önálló osztály végezte egészen a rendszerváltásig. ${ }^{35}$

A katonai hírszerzés/felderítés szakmai utódszervezeteként 1950. I. 1-én alakult meg a HM IV. Főcsoportfőnökség RÉvÉSZ Géza altábornagy vezetésével és egyben megszünt a HM Katonapolitikai Csoportfönökség.

HM IV. Főcsoportfönökség kezdetben három fő szervezeti elemből állt: Hírszerző Csoportfőnökség, Tájékoztató Szolgálat, RÁF. Szolgálat.

1953 végén - a szovjet igényeknek megfelelően - a felderítő főcsoportfönökséget a HM állományából a Vezérkar állományába helyezték át, a vezérkari fönök közvetlen alárendeltségébe. Elnevezése VK. 2. Csoportfőnökségre változott. Szervezeti 1956 végéig négy fő részlegből állt: Operatív Szolgálat (hírszerző részleg), Tájékoztató Szolgálat (elemző-értékelő részleg), Rádiófelderítő Szolgálat, Kiképzési és ellátó Szolgálat.

A hírszerzés/felderítés fö irányait képezte 1955-ig Jugoszlávia, valamint az Egyesült Államok szárazföldi és légi haderőnemei képességeinek felfedése. Fontos cél országok voltak: Ausztria, Németország, Olaszország, Franciaország, Görögország, és Törökország.

A Magyar Néphadsereg Vezérkarának 2. Csoportfönökségére változott 1957-ben a katonai hírszerzés szervezetének elnevezése és a szervezeti rendje módosult. Az új szervezet: Operatív Szolgálatból, Tájékoztató Szolgálatból, Rádióelektronikai Szolgálatból, Csapatfelderítő Szolgálatból és Anyagitechnikai Szolgálatból állt.

A Rádióelektronikai szolgálat legfontosabb szervezeti egysége a Rádiófelderítő osztály volt, amely: Hadműveleti alosztályból, Kiképző alosztályból, Technikai fejlesztő alosztályból, Rejtjelmegfejtő alosztályból és Híradó alosztályból állt.

Az alosztályok a későbbiek során osztályszintü szervezetté alakultak át és így is müködtek egészen a rendszerváltásig. ${ }^{36}$

A rádió felderítő szolgálat csapattagozata lényegében követte a két világháború között müködő hasonló szervezetek megnevezését. A 101., a 102., és a 103. rádió felderítő zászlóaljakból került megalakításra a 102., illetve a 3. önálló hadászati rádió felderítő ezred, majd pedig - 1983-tól - a 3. önálló hadászati rádió felderítő dandár. Ezek a szervezetek Budapesten a Budekeszi úti laktanyában nyertek elhelyezést. A rádió felderítő dandár feladatát és tevékenységét a megalakulást követően még áthatotta a Varsói Szerződés tagságból eredő kötelezettség.

1956-ot követően a polgári és a katonai hírszerző szervek a párt adminisztratív osztályához voltak „,bekötve”, de müködött az együttmüködés és adatszolgáltatás a Varsói Szerződés partnerországok, különösen pedig a szovjet társszervek felé.

Összegezve megállapítható, hogy az ezred, majd pedig a dandár képességei és technikai ellátottsága megfelelt a kor színvonalának. Teljesítményüket tekintve pedig felvették a versenyt a korabeli hasonló adottságokkal rendelkező államok rádió felderítő szervezeteivel. A rejtjelfejtő tevékenység 1962-ig, szigorúan elkülönítve a rádiófelderítést végző szervezetektől, olykor még más helyőrségben is, a Rádió felderítő Szolgálat irányítása alatt folyt. Később azonban ezt a munkát az információszerző 
szervezethez rendelték, lényegében szakítottak az „X” alosztály müködési rendjével és ezzel megszünt a szakterület hitelességének belső kontrollja.

Jegyzetek:

${ }^{1}$ „A k korszerủ rádiófelderítés (angolul COMINT — Communication Intelligence) : a rádióelektronikai felderítés (SIGINT — Signal Intelligence) részeként rádiófelderítő, rádióiránymérő, elektromágneses jelanalizátor- desifrtáor-berendezésekkel a rádiófrekvenciás tartományokban müködő távközlési rendeltetésű elektromágneses sugárforrások felfedését, térbeli elhelyezkedésének és technikai jellemzőinek meghatározását, jeleinek rögzítését, megfejtését célzó szervezett tevékenység" Rádiófelderítés.

2. PILCH II. köt. 327-373.p.

${ }^{3 .}$ Loc.cit. : III.köt. 314-374.p.

${ }^{4 .}$ BALLA

${ }^{5 .}$ Loc.cit. : 1.p.

${ }^{6 .}$ A szövegkörnyezetben 18 rejtjelkulcs megfejtése szerepel, ugyanakkor a jegyzetek alcím 15. hivatkozásában 19 rejtjelkulcs összeállításáról van szó.

POKORNY : 132 .p.

${ }^{7}$ Loc.cit. : 73.p.

8. POKORNY visszaemlékezésére hivatkozó kutatók következetesen 10000 megfejtett táviratról tesznek említést, miközben a szerzö könyvében 10 000-12 000 megfejtett orosz dokumentumról tesz említést.

POKORNY : 132 .p.

9. GALÁNTAi : 100-110.p.

10.PARÁDI

${ }^{11 .}$ GALÁNTAI : op.cit.

12. A román támadás kezdetén az Osztrák-Magyar Monarchia 1. hadseregének állományába (parancsnok: ARTz Artúr tábornok) kezdetben csupán az 51., a 61. honvéd gyalog hadosztályok, valamint a 71. közös gyaloghadosztály tartozott. A 71. hadosztály alárendeltségébe tartozott a legendás 82. közös „Székely” gyalogezred, amely Pálos körzetében kiemelkedő harcászati sikereket ért el a román csapatokkal szemben.

Nagybaconi : 77. p.

${ }_{13}^{3}$ MADERSPACH : 191-192. p.

14. PILCH II. op.cit.

${ }^{15}$ A hírszerző állomások müködése súllyal a Balkánon, illetve Orosz-Lengyelországban összpontosult. A Nagy Háború időszakában a Hírszerző Osztály irányításával hírszerző állomások működtek: Pjotrkowban, Neu-Sandecben, Kowelben, Varsóban. A Balkánon: Cattaroban, Mostarban. Szerbia megszállását követően: Valjevoban, Mitrovicán, Kragujevacon, Novipazarban. Észak-Albániában: Skutariban. Montenegroban: Cetinjeben. Románia elleni hadjárat során: Kolozsvárott, Brassóban, Bukarestben, Jassiban és Galacon. Az olasz front megnyitását követően: Insbruckban, Grazban, Feldkirchben, Triesztben, Innichenben, Kötschachban, Wieselburgban. Svájcban: Züricben, Genfben, St. Morizban és St.Gallenben. A háború menetében a Svájcban létesültek hírszerző állomásoknak, ahol elsősorban az olasz hadvezetés terveinek megismerése iránt mutatott érdeklődést a Monarchia vezérkara. Az e forrásból a karintiai, és az isonzói csaták előkészületeiről jó időben sikerült beszerezni a legfontosabb információkat, amelyeket a Hírszerző Osztályon formáltak adatokká.

BALLA : op.cit. : 2.p.

${ }^{16}$ PUSZTASZERI : 40. p.

17.ÁBTL. A-857. Szentpétery György vk. ezredes vallomása. A 11-10. 138/51. sz. Obj. do. 5. sz. melléklete. A VKF-2-es beosztottakról. 306-307. p.

${ }^{18}$. PUSZTASZERI : op.cit. : 41. p.

${ }^{19}$ SZAKÁLY

20.SZAKÁLY idézett tanulmányában, illetve az ÁBTL/Corvina gondozásában megjelent: Vallomások a holtak házából, címü kötet 321. p. található 11. sz. jegyzetben is tényként közli, hogy Pokornyt az „X” alosztály élén KABINA Vilmos ezredes váltotta, aki 1935-ig vezette az osztályt. SzAKÁLY szerint KABINit PETRIKOviTs István ezredes követte az osztály élén, aki ott is maradt 1945-ig. (Ld. Felderítő Szemle 2008. november. 27. p.) Ezzel szemben SzENTPÉTERY György ezredes az ÁVH-nak tett vallomásában azt állítja, hogy miután átvette a KOFFA vezetését az akkor már nyugdíjba helyezett POKORNY altábornagy reaktiválására ő tett javaslatot. A tábornok így került ismét az „X” alosztály élére. A tábornok 1938-ig töltötte be ezt a beosztást, amikor is végérvényesen nyugállományba helyezték. (ÁBTL. 11-10. 138/51. sz. Obj. do. 5. sz. melléklet. 306. p.) SZENTPÉTERY közlését visszaemlékezésében magerősíti POKORNY vezérezredes is azzal a pontosítással, hogy őt 1935 augusztusában SOMKÚTHY tábornok, vezérkari fönök kérte föl a VKF-2 sifre osztályának vezetésére és a dezinformációs szolgálat megszervezésére.

POKORNY : 126.p.

${ }^{21}$ BAJNAI

22.A VKF-2 szervezetei voltak: Nyilvántartó alosztály (NYIL), Központi offenzív alosztály (KOFFA), Defenzív alosztály (DEF), „X” alcsoport, Attasé alcsoport, Közigazgatási alcsoport, Szabotázs alcsoport, Bakteriológiai alcsoport. ÁBTL : op.cit. 288-293.p.

${ }^{23}$ Felderítő Szemle 2010. júniusi számának 159-166. p. R.L A Magyar rádiófelderítés a II. világháborúban című tanulmány szerzője idősíkokat figyelmen kívül hagyva, félreérthető módon - több alkalommal forrás feltüntetése nélkül - közöl olyan tényadatokat, amelyeknek a valóságtartalma megkérdőjelezhető. A kifogásolható állításokat szakmai szempontból megvizsgálva arra a következtetésre juthatunk, hogy a szerző nincs tisztában az általa vizsgált hírszerző szervezetek és azok képviselőinek, vagy vezető munkatársainak jog- és hatáskörével. Mind ez vonatkozik az „X” alosztály, szerző által felemlített, nagyfokú önállóságának a sejtetésére is. A jobb megértéshez tartozik, hogy a rejtjelző alosztály a VKF-2 beosztott alosztálya volt, bár feladatait önerőből és rejtett módon végezte, de az általa megszerzett információkat nem kezelhette saját belátása szerint. Az adattá formált információk átadása csak és kizáróan az osztály vezetőjének intézkedése szerint és a legfelső 
katonai vezetés tudtával és beleegyezésével történhetett. Amennyiben a VKF-2 osztály vezetője adatcsere keretében tájékoztatást adott ki a partnerei részére, még azt is köteles volt ledokumentálni, és a tárgyalásairól tájékoztatást adni a felettes szerveknek. Nyilvánvaló tehát, hogy az „X” alosztály, illetve a német társszervek közötti szoros együttmüködést hiba úgy beállítani, mint az alosztály öntevékeny kezdeményezését, amelyet a felettes szerv megkerülésével folytatott volna.

24.ÁBTL : op.cit. 293.p.

${ }^{25}$ SZENTPÉTERYVEL szemben UJSZÁSZY tábornok, a VKF-2 osztály egykori vezetője az őt kihallgató ÁVH embereinek úgy nyilatkozott, hogy a MELCZER csoport az „X” alosztály alárendeltségében müködött. (HARASZTı György, Vallomások a holtak házából, UJSZÁszY István vezérörnagynak, a 2. vkf. osztály (helyesen: VKF-2. osztály) és az Államvédelmi Központ vezetőjének az ÁVH fogságában írott feljegyzései. Nem lehet kétséges, hogy UjSzÁszY vezetése alatt történtek átszervezések az osztálynál, ugyanakkor az idézett müben a szervezeti rendre vonatkozóan egymásnak ellentmondó adatok szerepelnek, amely arra enged következtetni, hogy a visszaemlékező az adott pillanatban bizonytalan volt az osztály szervezeti rendjének pontos közlésében. Mindennek ellenére nem zárható ki, hogy a MELCZER csoport, UJSZÁszy osztályvezetése idején, az „X” alosztály alárendeltségébe került.

ÁBTL. : op.cit. : 288-304.p.

26.ÁBTL : op.cit. : 312.p.

${ }^{27}$ A 101. híradó ezred Budapesten a Károly király laktanyában volt elhelyezve, ma Petőfi laktanya, Budaörsi út. 49-53.

${ }^{28 .}$ BAJNAI : op.cit. 48-51.p.

${ }^{29}$ CSÓKA

${ }^{30}$ Loc.cit. : 20.p.

${ }^{31}$ Katonapolitikai Osztály = KATPOL. Székhelye: Budapest, Nádor utca. Vezetője: PÁLLFY György altábornagy.

${ }^{32 .}$ BAJNAI : op.cit. 56.p.

${ }^{33}$ A rádiólehallgató csoportból hazatérésüket követően a KATPOL-nál is szolgálatot vállalt MELCZER Dezső ezredes, HoRVÁTH Ferenc alezredes, ANDREÁNSZKY István őrnagy.

34.ÁBTL : op.cit. : 197-199.p.

${ }^{35}$ A polgári hírszerzés későbbi szerveinek jogelődei az ÁVH vonatkozó főosztályai voltak. Ez igaz a katonai elhárításra is. CSEH

${ }^{36 .}$ BAJNAI : op.cit. 56-59.p.

\section{A jegyzetekben alkalmazott röviditések: \\ MONOGRÁFIÁK}

GALÁNTAI

MADERSPACH

Nagybaconi

PILCH

POKORNY

PUSZTASZERI

\section{TANULMÁNYOK}

BAJNAI

CsÓKA

PARÁDI

GalánTAI József: A Habsburg-monarchia alkonya. Osztrák-magyar dualizmus 1867-1918. Budapest, 1985, Kossuth. 386 p. HU-ISBN 9630925893.

MADERSPACH Viktor: Az oláhok vérnyomában a Fekete-tengerig. Budapest, 2007, Masszi kiadó.

Nagybaconi NAGY Vilmos: A Románia elleni hadjárat 1916-1917. I. kötet.

PILcH Jenő: A hírszerzés és kémkedés története. I-III.köt. Budapest, 1936, Franklin.

POKORNY Hermann: Emlékeim, a láthatatlan hírszerzö. Budapest-Kalocsa, 2000, Petit Reál-KaloPrint. 168 p. HU-ISBN 963926703 1. /Hadtörténeti Levéltári Közlemények./ HU-ISSN 1417-9598.

PuszTASzERI László: Karády és Ujszászy. Párhuzamos életrajz történelmi háttérre. Budapest, 2008, Kairosz kiadó.

BAJNAI Gusztáv: A magyar rádiófelderítés kialakulása és működése a kezdetektől a II. világháború végéig. Felderitö Szemle, (2007) julius 38-41.p.

CsóKA Ferenc: Csendőrség és hírszerzés 1930-1945. Rendvédelem-történeti Füzetek (Acta Historiae Preasidii Ordinis), HU-ISSN 1216-6774. VII.évf. (1997) 8.sz. 17-20.p. HU-ISSN 1216-6774. A tanulmány korábbi változata 1996 október 29.-én Budapesten hangzott el a Szemere Bertalan Magyar Rendvédelem-történeti Tudományos Társaság által szervezett rendvédelem-történeti tudományos konferenciasorozatnak „A napóleoni közbiztonsági örtestület útja Párizstól - Itálián és Ausztrián keresztül — Budapestig." címü VIII. konferenciáján. A publikált tanulmány az előadás javított, bővített és átdolgozott változata

PARÁDI József: Az Evidenzbüro. 33-54.p. In BoDA József — PARÁDI József — SimON F. Nándor (szerk.): A XIX-XX. századi magyar állam nemzetbiztonsági szervezetei. Budapest, 2013. Nemzetbiztonsági Szakszolgálat. 358 p. HU-ISBN 978963 0858564 .

SZAKÁLY

SZAKÁLY Sándor: Az önálló magyar katonai hírszerzés és kémelhárítás létrehozása és múködése a két világháború közötti Magyarországon 1918-1945. Felderitö Szemle, (2008) november 22-27. p.

\section{KÉZIRATOK}

BALLA

BALLA Tibor: Az osztrák-magyar hirszerző és kémelháritó szolgálat szervezése és müködése az I. világháborúban.

(Kézirat a szerző birtokában.) 
LEXIKONOK

Rádiófelderítés.

- Rádiófelderítés. Hadtudományi Lexikon. Budapest, 1995, Magyar Hadtudományi Társaság. HU-ISBN 963045226 X.

LEVÉL- IRAT- ÉS DOKUMENTUMTÁRAK

ÁBTL — Állambiztonsági Szolgálatok Történeti Levéltára

VILÁGHÁLÓS HIVATKOZÁSOK

CSEH

CSEH Gergő Bendegúz: A magyarországi állambiztonsági szervek intézménytörténeti vázlata (1945-1990).

Világhálón: http//www.abtl.hu/html/hu_11_1_intézmény_tort.html 


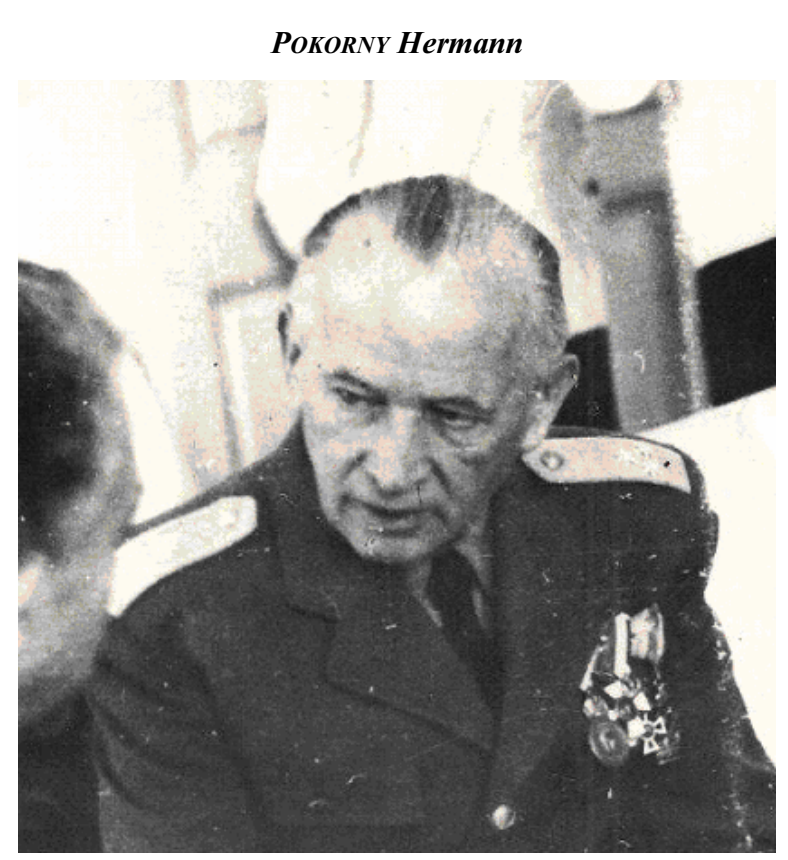

POKORNY Hermann az 1945 utáni magyar honvédség nyá. vezérezredeseként.

(Kremsier, Morvaország 1882.IV.7. - Budapest, 1960.)

Nyelvismerete: Német, cseh, latin, orosz, bolgár, lengyel, francia, olasz, magyar.

Iskolái: 1900. Bécsi Landwehr Hadapródiskola ; Bécs, 1906. Császári és Királyi Hadiiskola.

Rangfokozati elömenetel: 1900.VIII.18. hadapród tiszthelyettes ; 1901.IX.1. hadnagy ; 1906.XI.1. föhadnagy ; 1910.V.1. vezérkari százados ; 1917.V.1. vezérkari alezredes ; 1921. vezérkari ezredes ; 1925. gyalogsági tábornok ; 1928. altábornagy ; 1945. nyugállományú vezérezredes.

Kitüntetései: Katonai Jubileumi Kereszt./1848-1908/ ; Katonai Érdemkereszt III. osztálya hadidíszítménnyel ; Porosz Vaskereszt II. osztálya ; Osztrák Császári Vaskorona Rend III. osztálya hadidíszítménnyel ; Porosz Vaskereszt I. osztálya ; Török Vasfélhold (ottomán hadi érem) ; Bronz Katonai Érdemérem a Katonai Érdemkereszt szalagján a kardokkal ; Lipót Rend Lovagkeresztje hadiékítménnyel és kardokkal ; Vöröskereszt Tiszti Díszjelvénye hadidíszítménnyel ; Porosz Koronarend II. osztálya a kardokkal ; Török Ozmán Rend III. osztálya a kardokkal ; Bolgár Katonai Érdemrend hadi ékítménnyel ; Nagy Katonai Érdemérem a Katonai Érdemkereszt szalagján a kardokkal ; Orosz Vlagyimir Rend IV. osztálya ; Kormányzói Dícsérő Elismer (Koronás Bronz érdemérem) Piros-fehér szegélyủ zöld szalagon ; Katonai Tiszti Szolgálati Jel II. osztálya ; Magyar Háborús Emlékérem karddal és sisakkal ; Magyar Érdemkereszt II. osztálya a csillaggal (Magyar Érdemrend középkeresztje a csillaggal) ; Magyar Köztársasági Érdemrend középkeresztje a csillaggal ; Magyar Népköztársasági Érdemérem arany fokozata.

Életút: 1900. Bécsi 1. Landwehr gyalogezred ; 1906. 43. Landwehr gyalogdandár vezérkari tisztje ; 1909. szófiai féléves tanulmányút ; 1909. grazi székhelyü Császári és Királyi III. pk-on vezérkari tiszt ; 1910. Instruktionsbüro ; 1913 — kölcsönös vezénylés alapján — 3/4 éves oroszországi tanulmányút ; 1913. Evidenzbüro orosz referens ; 1914. Hadseregföparancsnokság Hadmüveleti Osztályának Rádiócsoport vezetője ; 1916. Evidenzbüro ; 1916. olasz front a 26. Landwehr Gyalogezred 2. Zászlóaljának parancsnoka ; 1916. Edelweiss Hadosztály vezérkari fönöke ; 1917. orosz béketárgyalásokon szakértő az Osztrák-Magyar Monarchia delegációjának tagjaként ; 1917. Evidenzbüro orosz referentúrájának vezetője ; 1918. novemberében belépett a magyar hadseregbe ; 1919. III. 5-én magyar állampolgárságot kapott ; Népköztársaság és Tanácsköztársaság ideje alatt a magyar Nyilvántartó Iroda munkatársa ; a Tanácsköztársaság bukása után debreceni vasi gyalogezred zászlóalj-parancsnoka ; 1920. titkos küldetéssel Krímbe utazott WrANGELhez, feladatát kiválóan teljesítette ; 1925 -ig a Vezérkari Főnökség Nyilvántartó Iroda „X alcsoport”-jának vezetője ; 1925. a szegedi honvéd kerület V. honvéd vegyesdandár gyalogsági parancsnoka ; 1926-ban budapesti vámőrkerület parancsnok ; 1928-ban a Magyar királyi Vámőrség felügyelője ; 1930-ban a miskolci VII. vegyesdandár parancsnoka ; 1934. szabályzatszerkesztő bizottság vezetője ; 1935. május nyugdíjazás ; 1960. elhunyt, sírja a gödöllői Dózsa György úti temetőben.

POKORNY Hermann hozta létre az Osztrák-Magyar Monarchia felderítésének rádiófelderítő szolgálatát, majd a Habsburgbirodalom felbomlása után a magyar rádiófelderítést. Mindkét felderítői szakszolgálat kiválóan müködött, példamutató eredményeket ért el.

Forrás ! ZEIDLER Sándor: POKORNY Hermann vezérezredes kitüntetései és ami mögötte van. 55-100.p. In BODA József — PARÁDI József — SimON F. Nándor (szerk.): A XIX-XX. századi magyar állam nemzetbiztonsági szervezetei. Budapest, 2013. Nemzetbiztonsági Szakszolgálat. 358 p. HU-ISBN 9789630858564. 